Sławomir Bralewski (Łódź)

\title{
The Labarum - From Crux Dissimulata and Chi-Rho to the Open Image Cross
}

$\mathrm{I}$ nitially, the battle banner called the labarum was presented in the form of crux dissimulata crowned with the Chi-Rho symbol. This practice dates all the way back to Eusebius of Caesarea (ca. 264-ca. 340). In the next century, the continuers of his Church History, Socrates of Constantinople and Sozomen, kept only the cross-shape of the banner, excluding the christogram. In this article, I will try to explain why this happened.

The creation of the labarum was associated with the so-called Constantine breakthrough and the conversion of Constantine the Great to Christianity. The reformation of the emperor was said to have taken place suddenly ${ }^{1}$, as a result of a vision ${ }^{2}$ which the ruler supposedly experienced before defeating his rival, Maxentius. It has aroused serious controversy and, in the literature of the subject, there is an ongoing discussion about its historicity and the form of the sign revealed to the emperor. Information about it comes basically from two sources: the accounts

\footnotetext{
${ }^{1}$ Hence, A. Alföldi (The Conversion of Constantine and Pagan Rome, trans. H. Mattingly, Oxford 1969 , p. 7) pointed out that Constantine's conversion happened without any warning, and as Ramsay MaCMullen put it (Constantine and the Miraculous, GRBS 9, 1968, p. 81): One day saw Constantine a pagan, the next a Christian. H. Singor (The Labarum, Shield Blazons and Constantine's Caeleste Signum, [in:] The Representation and Perception of Roman Imperial Power, ed. L. BloIs, Amsterdam 2003 , p. 500) noted that the aforementioned vision from 312, which resulted in the emperor's sudden conversion, played the symbolic role of the ruler's baptism.

${ }^{2}$ The literature on the subject is very rich. See, among others: W. Seston, La vision païenne de 310 et les origines du chrisme constantinien, AIPHOS, Mélanges F. Cumont 4, 1936, p. 373-395; A. ZIó£KowsKI, Wizja Konstantyna. Reinterpretacja, VP 4, 1983, p. 200-215; A. ŁukASzewicz, A propos du symbolisme impérial romain au IV siècle: Quelques remarques sur le christogramme, Hi 39.4, 1990, p. 504-506; O. Nicholson, Constantine's Vision of the Cross, VC 54, 2000, p. 309-323; P. Weiss, The Vision of Constantine, JRA 16, 2003, p. 237-259; J.W. Drijvers, The Power of the Cross - Celestial Cross Appearances in the Fourth Century, [in:] The Power of Religion in Late Antiquity, ed. A. CAIn, N. Lenski, Farnham 2009, p. 239-241; J. Long, How to Read a Halo. Three (or More) Versions of Constantine's Vision, [in:] The Power of Religion..., p. 227-235; J. BARdill, Constantine, Divine Emperor of the Christian Golden Age, Cambridge 2011, p. 159-183.
} 
of Lactantius ${ }^{3}$ and Eusebius of Caesarea ${ }^{4}$, which differ in detail 5 . In a fairly common opinion of researchers they both were trusted imperial advisers. When writing about the vision, Eusebius referred to the testimony of the ruler himself ${ }^{6}$. However, there are also supporters of a thesis that this vision was preceded by a pagan one. A pagan panegyric from 310 informs that it happened near the Temple of Apollo Grannus, identified with Sol Invictus, located in the city of Grand ${ }^{7}$. Some historians think that in reality, only the latter took place, but over time, it was interpreted in the Christian spirit ${ }^{8}$. Others, on the other hand, considered Constantine's vision

${ }^{3}$ Lactantius, De mortibus persecutorum, XLIV, 5, ed. J. Moreau, Paris 1954 [= SC, 39] (cetera: LaCtantius). Cf. T.D. Barnes, Constantine and Eusebius, Cambridge Mass.-London 1981, p. 13; IDEM, Lactantius and Constantine, JRS 63, 1973, p. 31-32.

${ }^{4}$ Eusebius, Vita Constantini, I, 28, 1-2, ed. F. Winkelmann, Berlin-New York 2008 (cetera: EuseBIUs). Lactantius' On the death of persecutors and Eusebius' Life of Constantine were written approximately a quarter of a century apart; the former was created in 314-315, and the latter in 337-340. ${ }^{5}$ According to Adam Zıó£Kowski (Wizja Konstantyna..., p. 200-215), despite the differences in details, the contents of the vision in both Lactantius' and Eusebius' accounts were similar and centered on the vexillum with the chrismon on top and the words hoc signo victor eris. H.A. Drake (Constantine and the Bishops. The Politics of Intolerance, Baltimore 2000 [= ASH], p. 180) also believes that Eusebius and Lactantius told the same story, although different in details. Raymond VAN DAM (The Many Conversions of the Emperor Constantine, [in:] Conversion in Late Antiquity and the Early Middle Ages. Seeing and Believing, ed. K. Mills, A. Grafton, Rochester 2003, p. 135-137), thought that there had been several visions and several conversions in the life of Constantine.

${ }^{6}$ Eusebius himself tried to suggest that he became the trusted confidant of the emperor. However, according to Timothy Barnes (Constantine and Eusebius..., p. 266), Eusebius had the opportunity to talk to Constantine but four times and may not have heard about the vision in a private conversation. T. Tоом (Constantine's Summus Deus and the Nicene Unus Deus: Imperial Agenda and Ecclesiastical Conviction, VP 34, 2014, p. 105, n. 15) noted that while Constantine swore to Eusebius about his vision, he did not confirm that Eusebius' interpretation was correct and accurate.

${ }^{7}$ Panegyric, VI (VII), 21, 4-5, [in:] In Praise of Later Roman Emperors. The Panegyrici Latini, ed. et trans. R.A.B. Mynors, C.E.V. Nixon, B.S. Rodgers, Berkeley-Los Angeles-Oxford 1994. This vision was interpreted as an announcement on the part of Apollo, identified with Sol Invictus, of Constantine's long years of prosperity. According to Timothy Barnes (Constantine and Eusebius..., p. 36), the aforementioned panegyric does not prove that Constantine indeed had such a vision. It only expresses the views of its author. Adam Zıó£KowsKi (Wizja Konstantyna..., p. 214) had a similar opinion on this subject. Furthermore, he thinks that Constantine's pagan panegyrics do not contradict the Christian tradition of his vision, but even confirm it. Cf. also B. MüLleR-Rettig, Der Panegyricus des Jahres 310 auf Konstantin den Großen. Übersetzung und historisch-philologischer Kommentar, Stuttgart 1990.

${ }^{8}$ Henri Grégoire (La „conversion” de Constantin, RUB 36, 1930/1931, p. 256) referred to Constantine's vision as a legend, which dans sa forme primitive, est non pas chrétienne, mais païenne. Cf. also IDEM, La vision de Constantin «liquidée», B 14, 1939, p. 341-351; A. Piganiol, L'Empereur Constantin, Paris 1932, p. 50. A similar view was expressed by P. Weiss (The Vision of Constantine..., p. 258), who believed that Constantine's vision occurred in 310, and two years later, it was only interpreted in the Christian spirit. Cf. also K.M. Girardet, Konstantin und das Christentum: die Jahre des Entscheidung, 310 bis 314, [in:] Konstantin der Grosse. Geschichte - Archäologie - Rezeption. Internationales Kolloquium vom 10.-15. Oktober 2005 an der Universität Trier zur Landesausstellung Rheinland-Pfalz "Konstantin der Grosse", ed. A. Demandt, J. Engemann, Trier 2006, p. 69-80; B.M. Liftin, Eusebius 
to be literary fiction ${ }^{9}$. Some see it as a supernatural phenomenon ${ }^{10}$, whereas others as a natural phenomenon associated with the conjunction of several planets ${ }^{11}$, or with an optical phenomenon (the so-called halo) ${ }^{12}$. Discussion about it is extremely difficult because neither party is able to prove their case ${ }^{13}$.

According to Lactantius and Eusebius, be it in a dream ${ }^{14}$ or in reality, the ruler allegedly saw a sign that was an announcement of victory in the war against Maxentius ${ }^{15}$. Lactantius wrote about "the heavenly sign of God" (caeleste signum dei $)^{16}$, while Eusebius described a triumphal sign in the form of a luminous cross

on Constantine: Truth and Hagiography at the Milvian Bridge, JETS 55.4, 2012, p. 773-792. Henry CHADwick (The Early Church, London 1967, p. 126) also did not preclude this option.

${ }^{9}$ Cf. J. Bidez, A propos d'une biographie nouvelle de l'empereur Constantin, AC 1, 1932, p. 6; A. AlföLDI, The Conversion of Constantine..., p. 18. For a number of historians, such as Arnaldo MARConE (Pagano e cristiano. Vita e mito di Costantino, Roma-Bari 2002, p. 73), Eusebius' account of the vision is not credible, because he mentions the chrismon only in the Life of Constantine, and in his Church History, he makes no mention of it whatsoever. According to Noel Lenski (Constantine and the Cities. Imperial Authority and Civic Politics, Philadelphia 2016 [= EAf], p. 71), this proves that Constantine had not yet fully developed the story he would tell in 324 in his own mind, or that he was yet reluctant to broadcast it in the period immediately following the battle.

${ }^{10}$ Cf. N.H. Baynes, Constantine the Great and the Christian Church, London 1934, p. 9; P. Keresztes, The Phenomenon of Constantine the Great's Conversion, Aug 27, 1987, p. 97.

${ }^{11}$ Cf. F. Heiland, Die astronomische Deutung der Vision Konstantins, Jena 1948; J. GaGÉ, Le signum astrologique de Constantin et le millenarisme de Roma aeterna, RHPR 31, 1951, p. 181-223; M. DImaio, J. Zeuge, N. Zotov, Ambiguitas Constantiniana: The Caeleste Signum Dei of Constantine the Great, B 58, 1988, p. 333-360.

${ }^{12}$ Quite early, A.H.M. Jones (Constantine and the Conversion of Europe, Harmondsworth 1972, p. 96) interpreted the phenomenon which was the subject of the vision as a halo, also referring to it as a meteorological phenomenon elsewhere (p. 102). Cf. also T.D. BARnEs, The Conversion of Constantine, EMC 29, 1985, p. 385-387; P. WeIss, The Vision of Constantine..., p. 237-259; C.M. OdAHL, Constantine and the Christian Empire, London-New York 2004, p. 287, n. 15; N. LENSKI, The Reign of Constantine, [in:] The Cambridge Companion to Age of Constantine, ed. IDEM, Cambridge 2006, p. 67, 71; B.M. LifTin, Eusebius on Constantine..., p. 773-792.

${ }^{13}$ The more so because Constantine himself, as Pierre MARAval (La religion de Constantin, AHI 22,2013 , p. 24-25) recently pointed out, makes no mention of his vision or prophetic dream neither in his letters nor in any of his speeches that we have today. And since dreams and visions were a typical element of ancient historiography, in Maraval's opinion, it is pointless to inquire about their realness, especially since they were a way of expressing the meaning of specific events a posteriori. In the case of Constantine, they proved that the ruler himself and his contemporary Christians were convinced that God had given him the victory, which the emperor himself supposedly claimed on multiple occasions.

${ }^{14}$ According to Adam Zı́́£kowski (Wizja Konstantyna..., p. 214), the emperor experienced this vision in a dream, and its content was the vexillum with the chrismon on top and the words hoc signo victor eris.

${ }^{15}$ According to Eusebius (I, 28, 2), he was supposedly assured of it by a celestial inscription along

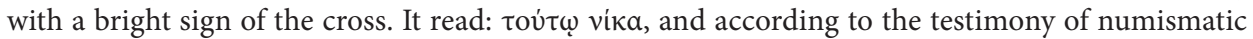
sources Hoc signo victor eris; cf. A. AlföldI, The Conversion of Constantine..., p. 7; C.M. OdAHL, Christian Symbols in Military Motifs on Constantine's Coinage, SAN 13.4, 1983, p. 71.

${ }^{16}$ Lactantius, XLIV, 5. 


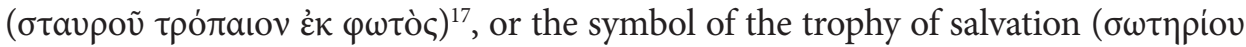
$\tau \rho o \pi \alpha i o v ~ \sigma \dot{\mu} \mu \beta \mathrm{o} \lambda \mathrm{ov})^{18}$. According to Eusebius, it took the shape of a military banner (vexillum) crowned with the chrismon, and called labarum ${ }^{19}$. When describing its appearance, Eusebius claimed that Constantine used to wear the monogram of Christ on his helmet, which was the quintessence of the revealed sign ${ }^{20}$. In the account of Lactantius, on the other hand, the celestial sign of God was placed on the shields of Constantine's soldiers ${ }^{21}$. In his description of Constantine's vision, Eusebius only mentioned the creation of the sign revealed to the emperor in the material form of a banner. However, a little further in his work, he also mentioned that Constantine ordered the placement of the sign-trophy of salvation ( $\sigma \omega \tau \eta \rho$ iov

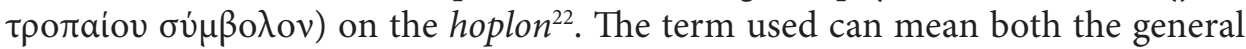
armament of soldiers, but also large shields - scutum ${ }^{23}$.

${ }^{17}$ Eusebius, I, 28, 1-2.
${ }^{18}$ Eusebius, IV, 21.
${ }^{19}$ Probably the name labarum was of Celtic origin; cf. J.-J. HATT, La vision de Constantin au sanctuaire
de Grand et l'origine celtique du labarum, CRAIBL 1, 1950, p. 83-86; W. SESTON, La vision païenne...,
p. 373-395. The labarum must have resembled a Roman cavalry banner made of fabric hung on
a horizontal bar (vexillum). Cf. M. DEsROCHEs, Le Labarum, Paris 1894; R. EGGER, Das Labarum, die
Kaiserstandarte der Spätantike, Wien 1960. C.M. ODAHL, The Celestial Sign on Constantine's Shields
at the Battle of the Mulvian Bridge, JRMMRA 2, 1981, p. 15-28. Adam EuKASZEWICZ (A propos du
symbolisme impérial..., p. 506) emphasized that the crown, which was on top of the labarum, but
also surrounded the christogram, was a symbol of victory and an imperial attribute at the same time.
In this way, Christ, who was symbolized by the sign, received imperial attributes. According to Henry
CHADwicK (The Early Church..., p. 126) the fact that the labarum was abolished during the reign of Julian the Apostate indicates that it was commonly attributed with a Christian meaning.

${ }^{20}$ Eusebius, IV, 21. Cf. C.M. Odahl, Christian Symbols on Constantine's Siscia Helmet Coins, SAN $8.4,1977$, p. $56-58$.

${ }^{21}$ Lactantius, XLIV, 5.

${ }^{22}$ Eusebius, IV, 21.

${ }^{23}$ In the late Roman Empire or early Byzantium's iconography, the tradition of decorating shields with the chrismon must have been present in the public consciousness if imperial propaganda referred to it. Aside from coins, there is evidence of it, e.g. on a gilded silver missorium with the portrait of Constantius II, probably on horseback (see S.G. МасCовмаск, Art and Ceremony in Late Antiquity, Berkeley-Los Angeles-London 1981, p. 43); reliefs from the column of Theodosius I (see the preserved fragment of the Theodosius column in the Beyazit Hamam Museum); the base of the Arcadius column in Constantinople (see J.H.W.G. Liebeschuetz, Barbarians and Bishops. Army, Church, and State in the Age of Arcadius and Chrysostom, Oxford 1992, p. 275), and a mosaic from the Basilica of San Vitale in Ravenna depicting the emperor Justinian and his entourage (see S.G. MacCormack, Art and Ceremony..., p. 259-266). As for the coins, in particular, we can point to the solidi of Constantius II, on which he was depicted with a shield decorated with the chrismon The Roman Imperial Coinage, vol. VIII, The Family of Constantine I, ed. J.P.C. Kent, London 1981 (cetera: RIC 8), Rome, 225, 232. Cf. D.M. ChIco, F.L. SÁnCHEz, Une nouvelle variété de solidus au nom de Constance II avec le chrisme à l'intérieur du bouclier, BSFN 71, 2016, p. 138-141; U. WeSTERMArk, A New Silver Medallion of Constantius II, NNA, 1968, p. 5-10), followed by similar coins minted by emperors Honorius (the solidus minted in 422, The Roman Imperial Coinage, vol. X, 
Therefore, it seems that the aforementioned discrepancy is only apparent. Firstly, we have iconographic evidence of both the military banner called the labarum, crowned with the monogram of Christ: the Chi-Rho, and shields decorated with that monogram. Secondly, the sign placed on the shields was intended not only to defend the soldiers, but also to lead them to victory, because according to Lactantius: quo signo armatus exercitus capit ferrum ${ }^{24}$. Eusebius, however, emphasized that the emperor used the labarum as a means of defense against all enemies ${ }^{25}$. Therefore, this banner was meant to lead them not only to the victorious attack but also to provide an effective defense against enemy assaults. Thirdly, when Eusebius and Lactantius described the difficult situation in which Constantine found himself on the eve of the battle at the Milvian Bridge, their accounts show that each of them saw the danger that threatened his army elsewhere. According to Lactantius, the emperor's worries were caused by the military superiority of Maxentius, who had capable commanders in his ranks. Moreover, aside from his army which he had brought from Africa and Italy, he also had his father's former army transferred from Severus ${ }^{26}$. Eusebius, on the other hand, thought that the emperor was troubled mainly by the wicked and deceptive magical practices employed zealously by Maxentius (I, 27 $)^{27}$. It is therefore not surprising that Lactantius paid attention to the sign placed on the shields, which was put there primarily to protect individual soldiers and ultimately, bring victory to Constantine, while Eusebius focused on the tropaion-banner, which was to be followed by the entire army, and by protecting Constantine's forces against magic, lead to victory.

It should be emphasized, however, that both in the account of Eusebius of Caesarea and Lactantius, the chrismon played a very important role in the vision of Constantine. The thread of the cross also appears in both texts - in the account of Eusebius directly and Lactantius indirectly. Eusebius claimed that in the afternoon, Constantine saw a triumphal sign in the sky above the sun. The sign had the form of a cross and was made of light. Later, according to the bishop of Caesarea, when the ruler commissioned a visual reproduction of the sign revealed to him (per Christ's direct command), its long shafts formed the shape of a cross

The Divided Empire and the Fall of the Western Parts AD 395-491, ed. J.P.C. Kent, London 1994 (cetera: RIC 10), Ravenna, 1332) and Majorian (RIC 10, 2605-2608; 2612-2614; 3748). According to D. Woods (Eusebius, VC 4.21, and the Notitia Dignitatum, [in:] SP 29, 1997, p. 196), the shield with the Chi-Rho was a special imperial shield. There are also a number of coins with the image of empresses: Aelia Flaccilla, Galla Placidia, Eudoxia and Pulcheria, on whose reverse an angel or Victoria is painting the chrisom on the shield.

${ }^{24}$ Lactantius, XLIV, 6.

${ }^{25}$ Eusebius, I, 31, 3.

${ }^{26}$ LaCtantius, XLIV, 3: Maxentiani milites praeualebant.

${ }^{27}$ The description of Lactantius, chronologically closer to the described events, seems to better reflect the difficult situation in which Constantine's armies found themselves on the eve of the battle at the Milvian Bridge. 
whose transverse rod was arched. Eusebius called this rod, to which a square piece of fabric was attached, the transverse cross beam. Below the sign of the cross, as described by the bishop of Caesarea, were the portraits of the emperor and his children. Eusebius described the banner as a sign of salvation ${ }^{28}$. In his Church History, he indirectly confirmed his account from Vita Constantini on the subject of the labarum. Mainly, he wrote about the statue of Constantine exhibited in Rome "with the sign of the Savior in his right hand", on which the emperor himself supposedly ordered the inscription: "in this sign of salvation, a real mark of bravery, I saved your city..." In fact, he quoted the inscription again in Vita Constantini, mentioning the statue in whose hand the tall, cross-shaped shafts were placed ${ }^{29}$. Hence, at that point already, Eusebius saw the cross in the labarum. However, his detailed description suggests that he meant the crux dissimulata. In a way, the very shape of the christogram also referred to the idea of the cross, since it was formed of the intersected Greek letters chi and rho. This can be seen even more clearly in Lactantius' text, where these intersected letters take the form of a monogramatic $\operatorname{cross}^{30}$.

He points out that the cross was clearly interpreted as a sign of victory, where Eusebius wrote about the cross as a symbol of immortality, a triumphant sign of Christ overcoming death ${ }^{31}$. Since the beginning of Christianity, the cross has been seen as a glorious sign of Christ's victory. Judeo-Christian theology was also a theology of glory. There, the cross was almost a living being, accompanying Christ in the works of His power, in the abyss or during the Parousia. Sometimes it was identified with Christ himself, usually with His victory ${ }^{32}$. In the First Apology, Christian Justin the Martyr calls the cross the greatest sign of power, Christ's might and His victory ${ }^{33}$. Justin explained to the pagans:

You also have the symbols that signify the power of the cross, that is, banners and trophies that go everywhere at the forefront of your army, showing a sign of might and power the way you cannot even surmise ${ }^{34}$.

\footnotetext{
${ }^{28}$ Eusebius, I, 31.

${ }^{29}$ Eusebius, I, 40.

${ }^{30}$ According to J.N. Bremmer, The Vision of Constantine, [in:] Land of Dreams. Greek and Latin Studies in Honour of A.H.M. Kessels, ed. A.P.M.H. Lardinois, M.G.M. van Der Poel, V.J.C. Hunink, Leiden 2006, p. 62, the expression used by Lactantius caeleste signum dei actually means the cross. ${ }^{31}$ Eusebius, I, 32, 2.

${ }^{32}$ J. DaniÉLOU, Histoire des doctrines chrétiennes avant Nicée. Théologie du judéo-christianisme, Paris 1991, p. 327-353.

${ }^{33}$ Justin (Iustinus, I Apologia, 55, 1-5, [in:] Justin, Philosopher and Martyr, Apologies, ed. D. Minns, P. PArvis, Oxford 2009 [= OECT], cetera: Iustinus) indicated that he is symbolically present everywhere as a hidden cross. According to him, nothing in the world can exist or make a whole without this sign. Its shape can be found in the masting of a ship, in hand and agricultural tools, and even in the human body.

${ }^{34}$ IUstinus, 55, 6.
} 
For Eusebius of Caesarea, the true sign of victory-triumph was therefore the cross of Christ, and although the labarum was a military flag, he saw it as the crux dissimulata.

Historians from the $5^{\text {th }}$ century emphasized the unique role of the sign of the cross in the religiousness of Christians in the first half of the $4^{\text {th }}$ century, and in particular, Constantine's, starting with his vision. When writing about it, they drew from the accounts of Lactantius and Eusebius, but they did not mention the chrismon, which supposedly revealed itself to the emperor. According to Rufinus $^{35}$, Philostorgius ${ }^{36}$, Socrates ${ }^{37}$ and Sozomen ${ }^{38}$, the ruler saw a sign in the shape of a cross, whether he was awake or dreaming, and was instructed in the form of an

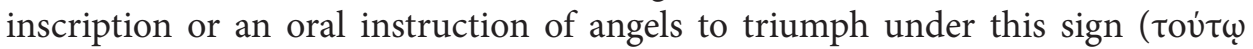
vika $)^{39}$. It is curious that these historians only saw the cross in the labarum ${ }^{40}$. According to Socrates, Christ commanded that a legionary battle sign with the

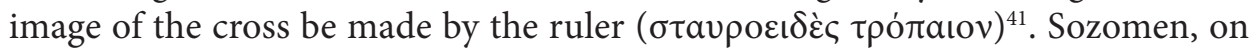
the other hand, emphasized that from that point forward, the war banner preced-

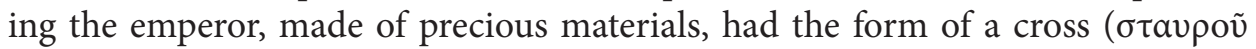
$\sigma v \mu \beta o \lambda o v)^{42}$, or that it was converted into a sign of the Holy Cross ${ }^{43}$. On the one hand, the banner was a symbol of certain triumph ${ }^{44}$, on the other, defense and

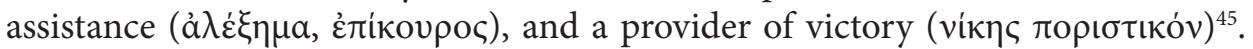
In the account of Sozomen, who followed the testimony of Eusebius of Caesa$\mathrm{rea}^{46}$, the priests who explained the meaning of the vision to the emperor indicated that the sign, which was revealed to him was a symbol of victory over hell ${ }^{77}$. In the

\footnotetext{
${ }^{35}$ Rufinus Aquileiensis, Historia Ecclesiastica, IX, 1-3, ed. E. Schwartz, T. Mommsen, F. WinkelMANN, Berlin 1999.

${ }^{36}$ Philostorgius, Kirchengeschichte, I, 6, ed. I. Bidez, F. Winkelmann, Berlin 1981 [= GCS].

${ }^{37}$ Socrates, Kirchengeschichte, I, 2, ed. G.C. Hansen, Berlin 1995 [= GCS.NF, 1] (cetera: Socrates).

${ }^{38}$ Sozomenus, Kirchengeschichte, I, 3, ed. J. Bidez, G.C. Hansen, Berlin 1995 [= GCS.NF, 4] (cetera: Sozomenus).

${ }^{39}$ P. JANISZEWSKI conducted a detailed analysis of four accounts (Żywioły w stużbie propagandy, czyli po czyjej stronie stoi Bóg. Studium klęsk i rzadkich fenomenów przyrodniczych u historyków Kościoła w IV i V wieku, [in:] Chrześcijaństwo u schyłku starożytności. Studia źródłoznawcze, vol. III, ed. T. Derda, E. Wipszycka, Kraków 2000, p. 40-44, 71sq, 102-104).

${ }^{40}$ There is no mention of the labarum in the preserved fragments of Philostorgius' Church History.

${ }^{41}$ Socrates, I, 2, 6-7.

${ }^{42}$ Sozomenus, I, $4,1$.

${ }^{43}$ Sozomenus, V, 17.

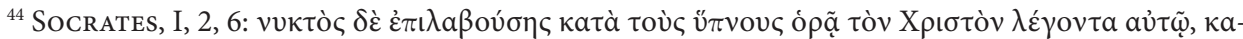

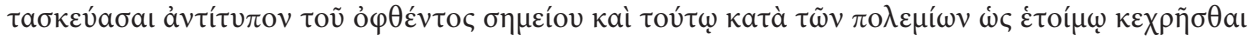
$\tau \rho о \pi \alpha i ́ \omega$.

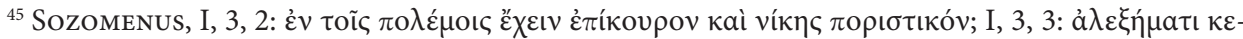

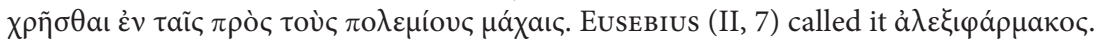

${ }^{46}$ Eusebius, I, 32.

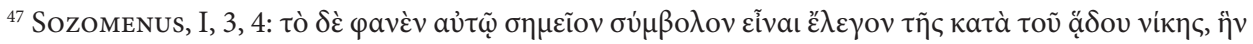

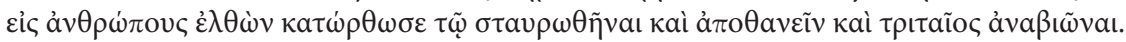


consciousness of Christians, it must have meant Christ's cross. This seems to be the main reason why the $5^{\text {th }}$-century church historians only saw the cross in the labarum.

An excellent example of the connection between the cross and the chi-rho is an ornament from the porphyry imperial sarcophagus, nowadays located in the courtyard of the Hagia Eirene Church in Istanbul (fig. 1). Numismatic evidence also cannot be ignored. The coins, as early as during the reign of Constantine the Great, included the Chi-Rho symbol both on the shields and on the labarum. The oldest example of a coin with a shield decorated with a christogram (fig. 2) is a bronze coin from 322-323 with a bust of Caesar Crispus ${ }^{48}$. Its counterpart with the labarum is a coin dated to 327 , minted on the occasion of the founding of Constantinople, on the reverse of which is the banner decorated with three medallions showing the portraits of Constantine and his two sons, Constantius II and Constantine II, with a shaft stuck into a winding snake (fig. 3$)^{49}$. After Constantine's death, starting with the reign of his sons, it happened that the coins minted then had a cross, instead of the Chi-Rho, on the labarum (fig. 4-6) ${ }^{50}$. The cross also began to be placed on the shields, in their central part, where the chrismon used to be, an example of which is the follis of Emperor Arcadius from 401-403, minted in Antioch (fig. 7) ${ }^{51}$. Over time, the cross replaced the entire labarum, as it happened during the reign of Valentinian III on the solidi of Gallia Placidia minted in Ravenna in the years $430-445$ (fig. 8 ) $^{52}$. The iconography present on the coins may prove that the phenomenon of identifying the labarum or Chi-Rho with the cross was not limited to church historiography and was more widespread, although it should be remembered that coins continued to also be decorated with the letters Chi-Rho. Therefore, the representation of the cross did not replace this symbol. However, it cannot be ruled out that the increasingly common image of the cross on coins also contributed to the aforementioned perception of the labarum by church historians.

Translated by Katarzyna Szuster-Tardi

\footnotetext{
${ }^{48}$ The Roman Imperial Coinage, vol. VII, Constantine and Licinius A.D. 313-337, ed. P.M. BRuUn, London 1966, Trier 372.

${ }^{49}$ Cf. F. KolB, Ideał późnoantycznego władcy. Ideologia i autoprezentacja, trans. A. GIERLIŃskA, Poznań 2008, p. 89; J. Williams, Religion and Roman Coins, [in:] A Companion to Roman Religion, ed. J. RüPKE, London 2007, p. 159.

${ }^{50}$ Constans, struck 337-340, RIC 8, Siscia 100; Constantius II, struck 337-340, RIC Trier 39; Constantius II, struck 347-355, RIC 8, Cyzicus 84.

${ }^{51}$ RIC 10, Antiochia 97.

${ }^{52}$ RIC 10, Valentinian III 2020.
} 


\section{Bibliography}

\section{Primary Sources}

Eusebius, Vita Constantini, ed. F. Winkelmann, Berlin-New York 2008.

In Praise of Later Roman Emperors. The Panegyrici Latini, ed. et trans. R.A.B. Mynors, C.E.V. Nixon, B.S. Rodgers, Berkeley-Los Angeles-Oxford 1994.

Iustinus, I Apologia, [in:] Justin, Philosopher and Martyr, Apologies, ed. D. Minns, P. Parvis, Oxford 2009 [= Oxford Early Christian Texts].

Lactantius, De mortibus persecutorum, ed. J. Moreau, Paris 1954 [= Sources chrétiennes, 39].

Philostorgius, Kirchengeschichte, ed. I. Bidez, F. Winkelmann, Berlin 1981 [= Die griechischen christlichen Schriftsteller der ersten [drei] Jahrhunderte].

Rufinus Aquileiensis, Historia Ecclesiastica, ed. E. Schwartz, T. Mommsen, F. Winkelmann, Berlin 1999.

Socrates, Kirchengeschichte, ed. G.C. Hansen, Berlin 1995 [= Die griechischen christlichen Schriftsteller der ersten [drei] Jahrhunderte. Neue Folge, 1].

Sozomenus, Kirchengeschichte, ed. J. Bidez, G.C. Hansen, Berlin 1995 [= Die griechischen christlichen Schriftsteller der ersten [drei] Jahrhunderte. Neue Folge, 4].

\section{Secondary Literature}

Alföldi A., The Conversion of Constantine and Pagan Rome, trans. H. Mattingly, Oxford 1969.

Bardill J., Constantine, Divine Emperor of the Christian Golden Age, Cambridge 2011.

BARnes T.D., Constantine and Eusebius, Cambridge Mass.-London 1981.

BARnes T.D., The Conversion of Constantine, "Échos du monde classique" 29, 1985, p. 371-391.

BARNes T.D., Lactantius and Constantine, "Journal of Roman Studies" 63, 1973, p. 29-46, https://doi. org/10.2307/299163

Baynes N.H., Constantine the Great and the Christian Church, London 1934.

Bidez J., A propos d'une biographie nouvelle de l'empereur Constantin, "Lantiquité classique" 1, 1932, p. 1-7, https://doi.org/10.3406/antiq.1932.2934

Bremmer J.N., The Vision of Constantine, [in:] Land of Dreams. Greek and Latin Studies in Honour of A.H.M. Kessels, ed. A.P.M.H. Lardinois, M.G.M. van Der Poel, V.J.C. HuninK, Leiden 2006, p. 57-79.

Chadwick H., The Early Church, London 1967.

Chico D.M., SáNChez F.L., Une nouvelle variété de solidus au nom de Constance II avec le chrisme à l'intérieur du bouclier, "Bulletin de la Société française de numismatique" 71, 2016, p. 138-141.

Daniélou J., Histoire des doctrines chrétiennes avant Nicée. Théologie du judéo-christianisme, Paris 1991.

Desroches M., Le Labarum, Paris 1894.

Dimaio M., Zeuge J., Zotov N., Ambiguitas Constantiniana: The Caeleste Signum Dei of Constantine the Great, "Byzantion. Revue internationale des études byzantines" 58, 1988, p. 333-360.

Drake H.A., Constantine and the Bishops. The Politics of Intolerance, Baltimore 2000 [= Ancient Society and History].

Drijvers J.W., The Power of the Cross - Celestial Cross Appearances in the Fourth Century, [in:] The Power of Religion in Late Antiquity, ed. A. CaIN, N. Lenski, Farnham 2009, p. 237-248. 
Egger R., Das Labarum, die Kaiserstandarte der Spätantike, Wien 1960.

GAGÉ J., Le signum astrologique de Constantin et le millenarisme de Roma aeterna, "Revue d'histoire et de philosophie religieuses" 31, 1951, p. 181-223, https://doi.org/10.3406/rhpr.1951.3267

Girardet K.M., Konstantin und das Christentum: die Jahre des Entscheidung, 310 bis 314, [in:] Konstantin der Grosse. Geschichte - Archäologie - Rezeption. Internationales Kolloquium vom 10.-15. Oktober 2005 an der Universität Trier zur Landesausstellung Rheinland-Pfalz "Konstantin der Grosse", ed. A. Demandt, J. Engemann, Trier 2006, p. 69-80.

Grégoire H., La „conversion” de Constantin, "Revue de l'Université de Bruxelles” 36, 1930/1931, p. 231-272.

GréGoire H., La vision de Constantin «liquidée», "Byzantion. Revue internationale des études byzantines" 14, 1939, p. 341-351.

Hатт J.-J., La vision de Constantin au sanctuaire de Grand et l'origine celtique du labarum, "Comptes rendus des séances de l'année de l'Académie des inscriptions et belles-lettres” 1, 1950, p. 83-86, https://doi.org/10.3406/crai.1950.78500

HeIland F., Die astronomische Deutung der Vision Konstantins, Jena 1948.

JANISZEWski P., Żywioły w stużbie propagandy, czyli po czyjej stronie stoi Bóg. Studium klęsk i rzadkich fenomenów przyrodniczych u historyków Kościoła w IV i V wieku, [in:] Chrześcijaństwo u schytku starożytności. Studia źródłoznawcze, vol. III, ed. T. Derda, E. WipszycKa, Kraków 2000, p. 11-190.

Jones A.H.M., Constantine and the Conversion of Europe, Harmondsworth 1972.

Keresztes P., The Phenomenon of Constantine the Great's Conversion, "Augustinianum" 27, 1987, p. 85-100, https://doi.org/10.5840/agstm1987271/28

Kolb F., Ideał późnoantycznego władcy. Ideologia i autoprezentacja, trans. A. GierlińsKA, Poznań 2008.

Lenski N., Constantine and the Cities. Imperial Authority and Civic Politics, Philadelphia 2016 [= Empire and After], https://doi.org/10.9783/9780812292237

Lenski N., The Reign of Constantine, [in:] The Cambridge Companion to Age of Constantine, ed. N. Lenski, Cambridge 2006, p. 59-90, https://doi.org/10.1017/CCOL0521818389.004

Liebeschuetz J.H.W.G., Barbarians and Bishops. Army, Church, and State in the Age of Arcadius and Chrysostom, Oxford 1992.

Liftin B.M., Eusebius on Constantine: Truth and Hagiography at the Milvian Bridge, "Journal of the Evangelical Theological Society" 55.4, 2012, p. 773-792.

Long J., How to Read a Halo. Three (or More) Versions of Constantine's Vision, [in:] The Power of Religion in Late Antiquity, ed. A. Cain, N. Lenski, Farnham 2009, p. 227-235.

ŁukAszewicz A., A propos du symbolisme impérial romain au IVe siècle: Quelques remarques sur le christogramme, "Historia. Zeitschrift für alte Geschichte" 39.4, 1990, p. 504-506.

MacCormack S.G., Art and Ceremony in Late Antiquity, Berkeley-Los Angeles-London 1981.

MacMullen R., Constantine and the Miraculous, “Greek, Roman, and Byzantine Studies” 9, 1968, p. 81-96.

Maraval P., La religion de Constantin, "Anuario de Historia de la Iglesia" 22, 2013, p. 17-35.

Marcone A., Pagano e cristiano. Vita e mito di Costantino, Roma-Bari 2002.

Müller-Rettig B., Der Panegyricus des Jahres 310 auf Konstantin den Großen. Übersetzung und historisch-philologischer Kommentar, Stuttgart 1990. 
Nicholson O., Constantine's Vision of the Cross, "Vigiliae christianae" 54, 2000, p. 309-323, https:// doi.org/10.1163/157007200X00189

Odahl C.M., The Celestial Sign on Constantine's Shields at the Battle of the Mulvian Bridge, "Journal of the Rocky Mountain Medieval and Renaissance Association” 2, 1981, p. 15-28.

Odahl C.M., Christian Symbols in Military Motifs on Constantine's Coinage, "SAN: Journal of the Society for Ancient Numismatics" 13.4, 1983, p. 64-72.

Odahl C.M., Christian Symbols on Constantine's Siscia Helmet Coins, "SAN: Journal of the Society for Ancient Numismatics" 8.4, 1977, p. 56-58.

Odahl C.M., Constantine and the Christian Empire, London-New York 2004, https://doi.org/ $10.4324 / 9780203449950$

Piganiol A., L'Empereur Constantin, Paris 1932.

The Roman Imperial Coinage, vol. VII, Constantine and Licinius A.D. 313-337, ed. P.M. BruUn, London 1966.

The Roman Imperial Coinage, vol. VIII, The Family of Constantine I, ed. J.P.C. Kent, London 1981.

The Roman Imperial Coinage, vol. X, The Divided Empire and the Fall of the Western Parts AD 395-491, ed. J.P.C. Kent, London 1994.

Seston W., La vision païenne de 310 et les origines du chrisme constantinien, "Annuaire de l'Institut de philologie et d'histoire orientales et slaves", Mélanges F. Cumont 4, 1936, p. 373-395.

Singor H., The Labarum, Shield Blazons and Constantine's Caeleste Signum, [in:] The Representation and Perception of Roman Imperial Power, ed. L. BLoIs, Amsterdam 2003, p. 481-500, https://doi. org/10.1163/9789004401631_037

Tоom T., Constantine's Summus Deus and the Nicene Unus Deus: Imperial Agenda and Ecclesiastical Conviction, "Vox Patrum. Antyk Chrześcijański" 34, 2014, p.103-122.

Van Dam R., The Many Conversions of the Emperor Constantine, [in:] Conversion in Late Antiquity and the Early Middle Ages. Seeing and Believing, ed. K. Mills, A. Grafton, Rochester 2003, p. 127-151.

Weiss P., The Vision of Constantine, "Journal of Roman Archaeology" 16, 2003, p. 237-259, https:// doi.org/10.1017/S1047759400013088

Westermark U., A New Silver Medallion of Constantius II, "Nordisk numismatisk årsskrift", 1968, p. 5-10.

Williams J., Religion and Roman Coins, [in:] A Companion to Roman Religion, ed. J. Rüpke, London 2007, p. 143-163, https://doi.org/10.1002/9780470690970.ch11

Woods D., Eusebius, VC 4.21, and the Notitia Dignitatum, [in:] Studia patristica 29, 1997, p. 195-202.

ZıóŁкошsкi A., Wizja Konstantyna. Reinterpretacja, "Vox Patrum. Antyk Chrześcijański” 4, 1983, p. $200-215$. 


\begin{abstract}
Based on the testimony of emperor Constantine the Great himself, Eusebius of Caesarea presented a labarum in the form of crux dissimulata crowned with the Chi-Rho. The continuers of his Church History in the next century, Rufinus of Aquileia, Philostorgius, Socrates of Constantinople, and Sozomen, only kept the cross-shape of the banner, excluding the christogram. This might have happened because in two main sources informing about the vision of Constantine - the accounts of Eusebius of Caesarea and Lactantius - it was not only the monogram of Christ that played a significant role. The motif of the cross also appears in them, in the account of Eusebius directly, and Lactantius indirectly. Furthermore, Christians interpreted the cross explicitly as a sign of victory. Eusebius wrote about the cross as a symbol of immortality, a triumphant sign of Christ overcoming death. In the account of the bishop of Caesarea, on the other hand, Constantine's supposed vision included a triumphal sign in the form of a luminous cross, or the symbol of the trophy of salvation. Numismatic evidence also cannot be ignored. Already during the reign of Constantine the Great, the Chi-Rho appeared on the coins both on the shields and on the labarum. However, starting from the reign of Constantius II, coins that were minted included the cross instead of the Chi-Rho on the labarum. It also began to be placed on the shields, in their central part, where the monogram of Christ used to be. Over time, the cross replaced the entire labarum. The iconography present on the coins may prove that the phenomenon of identifying the labarum or Chi-Rho with the cross was not limited to church historiography and was more widespread, although it should be remembered that coins continued to also be decorated with the letters Chi-Rho. Therefore, the representation of the cross did not replace this symbol. However, it cannot be ruled out that the increasingly common image of the cross on coins also contributed to the aforementioned perception of the labarum by church historians.
\end{abstract}

Keywords: labarum, Christ's cross, Constantine's vision, church historiography

\title{
Sławomir Bralewski
}

University of Lodz Faculty of Philosophy and History Institute of History Department of Byzantine Studies ul. Kamińskiego 27a 90-219 Łódź, Polska/Poland s.bralewski@o2.pl 


\section{ILLUSTRATIONS}

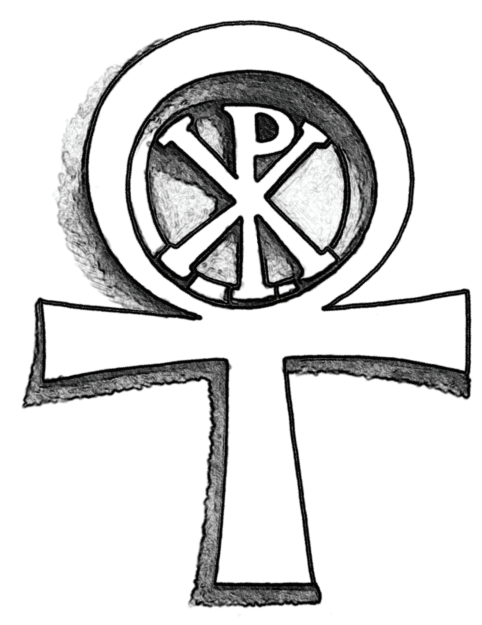

Fig. 1. The chi-rho is an ornament from the porphyry imperial sarcophagus, nowadays located in the courtyard of the Hagia Eirene church in Istanbul. All drawings in this article by ElżBieta MyśLińsKa-BrzozowsKa.

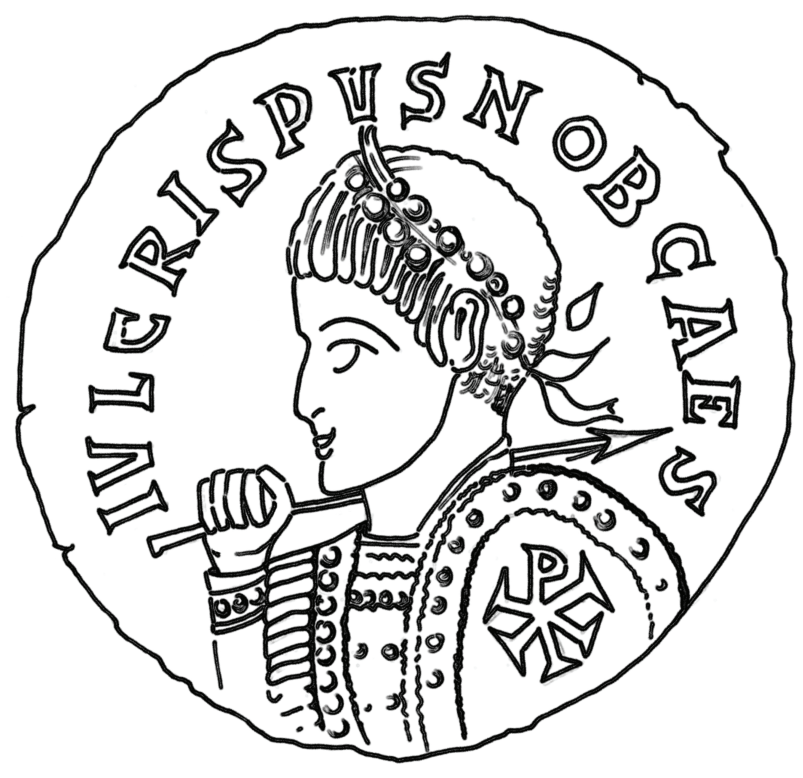

Fig. 2. The bronze from 322-323 with a bust of caesar Crispus (RIC 7, Trier 372). 


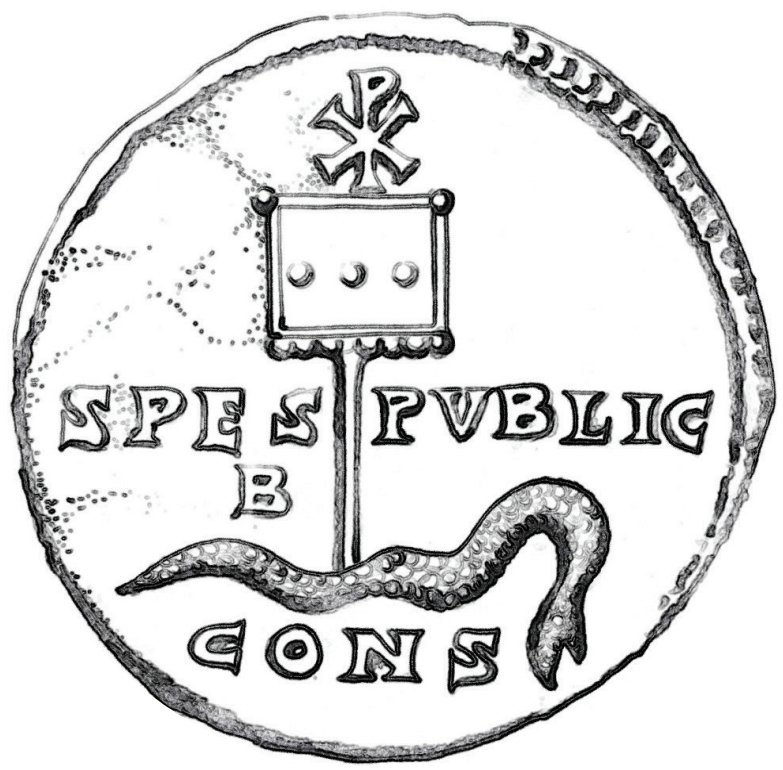

Fig. 3. The coin minted in 327 on the occasion of the founding of Constantinople, on the reverse of which is the banner decorated with three medallions showing the portraits of emperor Constantine and his two sons, Constantius II and Constantine II, with a shaft stuck into a winding snake (RIC 7, Constantinople 19).

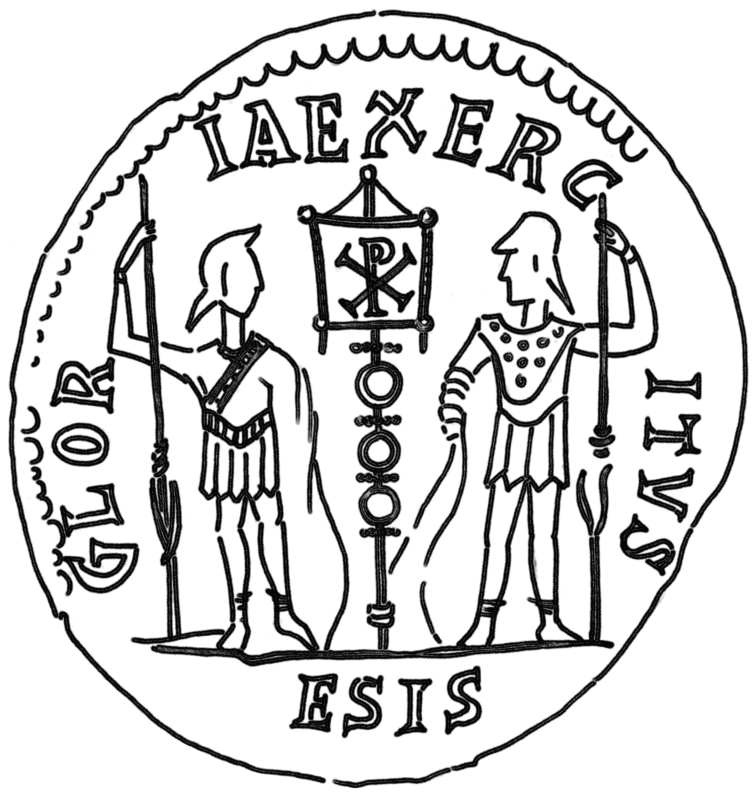

Fig. 4. The bronze of emperor Constans from 337-340, struck in Siscia (RIC 8, Siscia 100). 


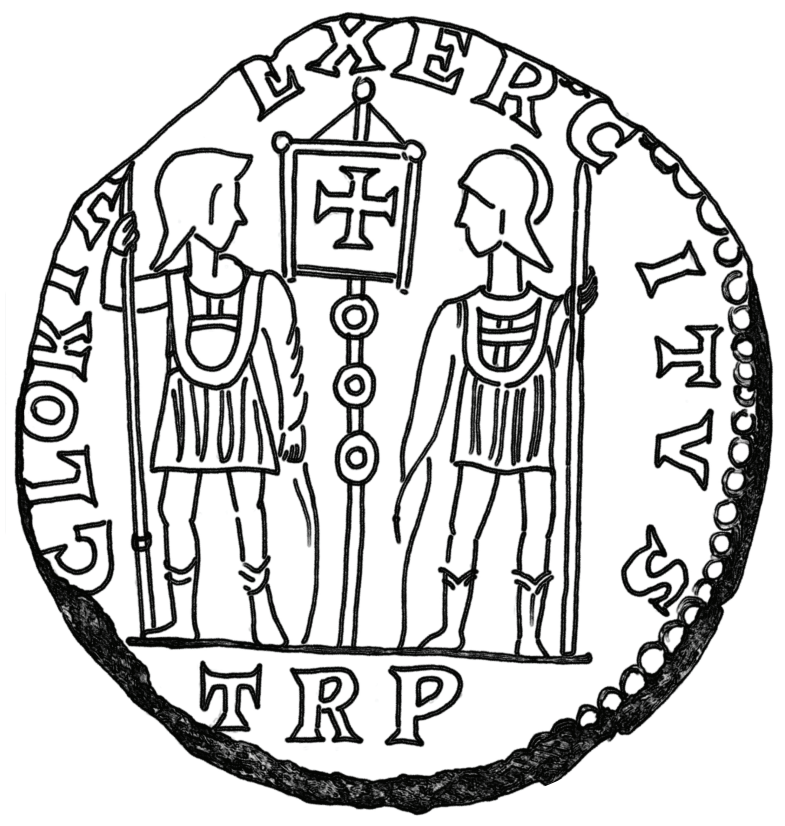

Fig. 5. The bronze of emperor Constantius II from 337-340, minted in Trier (RIC 8, Trier 39).

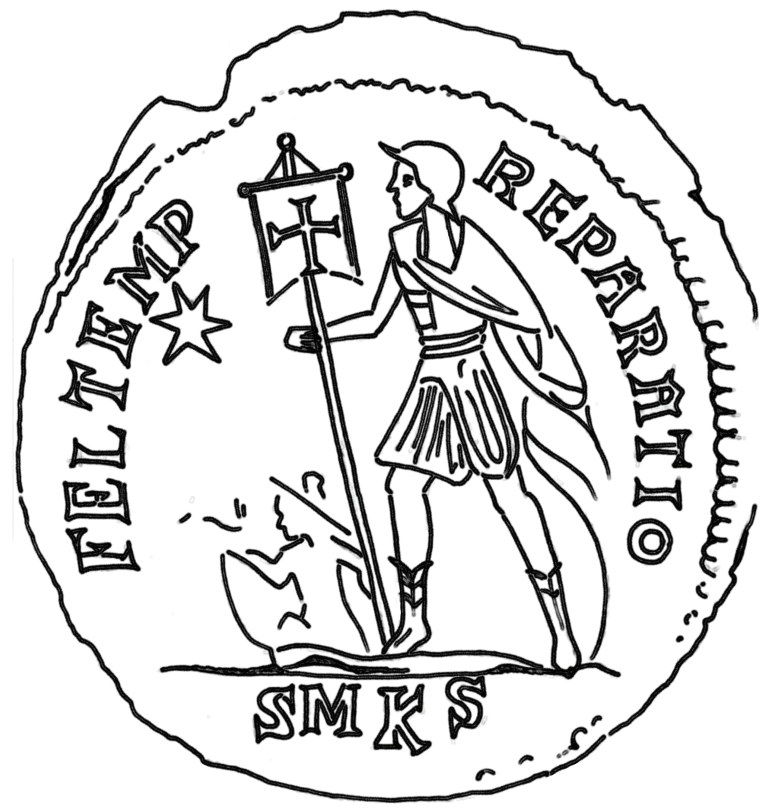

Fig. 6. The coin of emperor Constantius II from 347-355, struck in Cyzicus (RIC 8, Cyzicus 84). 


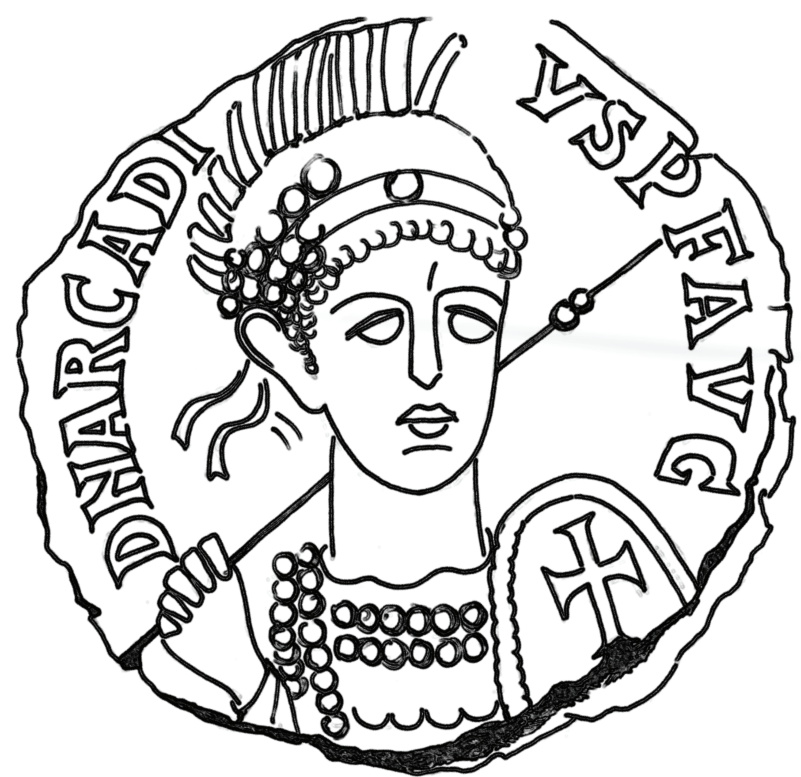

Fig. 7. The follis of Emperor Arcadius from 401-403, minted in Antioch (RIC 10, Antioch 97).

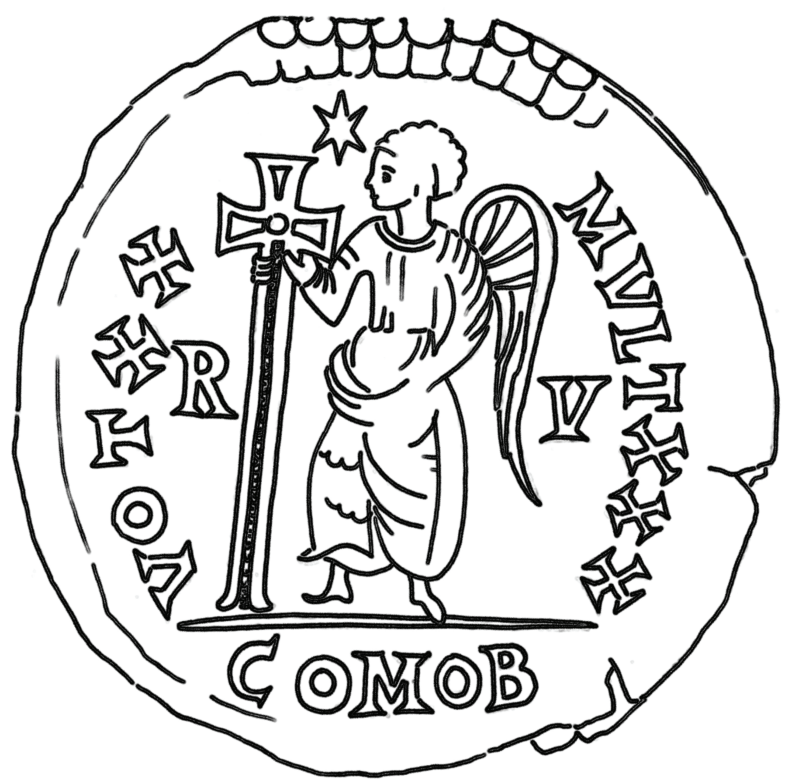

Fig. 8. The solidi of Gallia Placidia minted in Ravenna in the years 430-445 (RIC 10, Valentinian III 2020). 